\title{
Wildfire effects on stream food webs and nutrient dynamics in Glacier National Park, USA
}

\author{
Craig N. Spencer ${ }^{\mathrm{a},}$, Kristin Odney Gabel ${ }^{\mathrm{b}}$, F. Richard Hauer ${ }^{\mathrm{c}}$ \\ ${ }^{a}$ Biology Department, Augustana College, Sioux Falls, SD 57197, USA \\ ${ }^{\mathrm{b}}$ Eden Prairie Public Schools, Central Middle School, 8025 School Road, Eden Prairie, MN 55344, USA \\ ${ }^{\mathrm{c}}$ Flathead Lake Biological Station, 311 BioStation Lane, Polson, MT 59860, USA
}

\begin{abstract}
We documented immediate and mid-term (5 years) impacts on streams from a large (15,500 ha) wildfire in northwestern Montana. Fire-related impacts were ecosystem-wide, extending from water chemistry to fish. During the initial firestorm, phosphorus and nitrogen levels increased 5- to 60-fold above background levels resulting from aerial deposition from smoke and ash. Nutrients returned to background concentrations within several weeks after the fire. During subsequent years, nutrient concentrations periodically increased in fire-impacted sites compared to reference sites, especially during spring run-off.

Evidence of post-fire changes was also documented in the aquatic food web via stable isotope analyses. Macroinvertebrates and fish from fire-impacted sites were significantly more enriched in ${ }^{15} \mathrm{~N}$ and depleted in ${ }^{13} \mathrm{C}$ than consumers from forested reference sites $(P<0.001)$. The post-fire isotopic shift in consumers was consistent with increased utilization of algae and/or other autochthonous food sources together with decreased reliance on terrestrial leaf litter and other allochthonous food sources. Such a post-fire shift from a detritus based on a periphyton-based food web fits predictions of the river continuum concept following canopy removal and nutrient enrichment.

Following decades of active fire suppression, forest managers are now contemplating aggressive efforts to reduce the fuel build-up noted in forests throughout the western US. Such efforts could involve increased use of fire and mechanical thinning and harvest. Results from our work and others suggest that expanded fire activity could mobilize substantial quantities of highly available nutrients to lakes and streams. With significant nutrient delivery mechanisms involving water, as well as airborne transport via smoke and ash, the potential for increased nutrient loadings to surface waters could extend well beyond the catchment of any particular fire. As natural resource managers contemplate expanding the use of fire as a forest restoration tool, they face the dilemma that such efforts could run counter to a decades-long effort to reduce nutrient loadings to lakes and other surface waters threatened by eutrophication.
\end{abstract}

(C) 2003 Elsevier Science B.V. All rights reserved.

Keywords: Wildfire; Stream food webs; Nutrients; Stable isotopes

\section{Introduction}

At present, forest managers are wrestling with the challenging task of formulating forest management

\footnotetext{
* Corresponding author. Tel.: +1-605-274-4716; fax: +1-605-274-4718.

E-mail address: craig_spencer@augie.edu (C.N. Spencer).
}

plans for the new century. This comes in the wake of several extensive fire seasons in recent years, which followed decades of fire suppression in forests throughout the US. As forest managers debate the possibility of more aggressive forest management in the face of extensive fuel build-up in many forests, an important concern is the potential impact on aquatic ecosystems. The quality of aquatic ecosystems 
typically reflects both the natural and human-related aspects of the surrounding landscape. Evidence of declining water quality and the deteriorating status of many aquatic species in recent years provide clues that all is not well within many lake and river catchments. Although forest management practices do not represent the only area of concern, the possibility of more aggressive forest management in the future raises concerns about possible impacts on aquatic ecosystems.

In this paper, we present an overview of findings from an ongoing study of a large 1988 wildfire located mostly in Glacier National Park, Montana (Fig. 1). Our study focuses on the effects of wildfire on stream nutrients and aquatic food webs. There have been a limited number of studies on the effects of large wildfires on aquatic ecosystems. Those studies that have addressed the impacts of fires on stream nutrients reached different conclusions (see reviews by Tiedemann et al., 1979; Baker, 1990). Several early studies reported that large forest fires did not increase stream nutrient concentrations (Wright, 1976; McColl and Grigan, 1977). More recent studies indicate that large wildfires may contribute to elevated stream concentrations of nitrate, and sometimes ammonium and phosphate, for several or more years following the fires (Tiedemann et al., 1978; Gluns and Toews, 1989; Spencer and Hauer, 1991; Bayley et al., 1992; Brass et al., 1996; Hauer and Spencer, 1998).

During large fires, substantial quantities of particulates and volatile compounds are transported via the atmosphere and may produce large fluxes of nutrients in aquatic ecosystems (Spencer and Hauer, 1991) but water chemistry data are often lacking during the early stages of many fires that have been studied. This is especially true of large wildfires, and stems largely because such fires are unplanned and logistically difficult to study. In the present study, we summarize

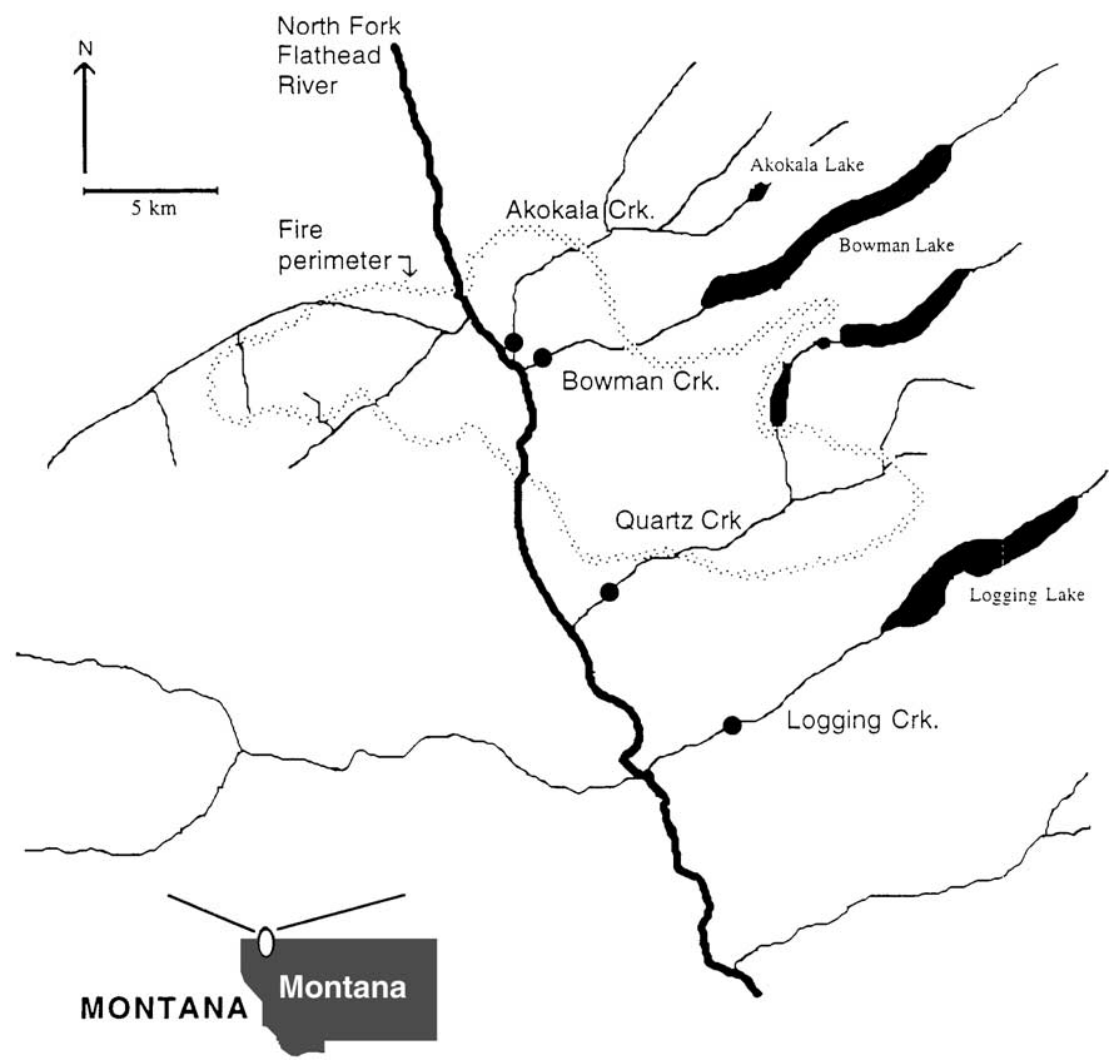

Fig. 1. Area of the 1988 Red Bench Fire in northwest Montana showing study sites (black dots) and fire perimeter. The area to the east of the North Fork of the Flathead River is in Glacier National Park. 
soluble nutrient data collected from several streams in the midst of the Red Bench Fire in Glacier National Park, as well as over the 5 years following the fire. A more comprehensive data set from the Red Bench Fire may be found elsewhere (Spencer and Hauer, 1991; Hauer and Spencer, 1998).

In addition to summarizing nutrient data, we present new findings dealing with the effects of the fire on the food web of our study streams. Small forested streams generally have allochthonous-based food webs, supported by substantial inputs of terrestrial plant material (Minshall, 1967; Fisher and Likens, 1973; Cummins et al., 1982). Following the extensive fire season of 1988 in the western US, Minshall et al. (1989) predicted a post-fire shift to more autochthonous-based stream food webs, resulting from reduced inputs of terrestrial vegetation following the fires together with expected stimulation of aquatic primary production due to increased availability of light and nutrients following the fires. This prediction stems largely from theories developed in the river continuum concept (Vannote et al., 1980). To date, little empirical evidence has been published to support or refute this prediction for fires, although similar effects have been documented for timber harvest (Hansmann and Phinney, 1973; Stockner and Shortreed, 1976; Feminella et al., 1989). In post-fire work in Yellowstone National Park, Mihuc and Minshall (1995) found that benthic macroinvertebrates were dominated by trophic generalists that appeared well-adapted to shifting between allochthonous and autochthonous food sources. In the present study, we measured stable carbon and nitrogen isotope ratios across a wide variety of organisms from the primary producers to fish to look for evidence of food web shifts following the Red Bench Fire.

\section{Methods}

\subsection{Study sites}

Prolonged drought in the western US contributed to the extensive fire season of 1988 when over 2 million ha of forest burned in Montana, Wyoming, and Idaho, representing the most extensive fire season since 1910 (Hauer and Spencer, 1998). The fires of 1988 included the Red Bench Fire, which began on 6 September and covered 15,385 ha, mostly in Glacier National Park (Fig. 1).

The Red Bench Fire burned substantial portions of the lower Akokala and Bowman creek catchments and we focused our studies on these two creeks. Sampling sites were established on both creeks including fireimpacted sites within the burned area, and reference sites located outside the fire perimeter (Fig. 1). We also collected water samples from Quartz creek; however, this stream was not accessible during the fire. All of the study streams are third-order, fast-flowing, nutrient-poor streams typical of Glacier National Park. Although the streams originate in alpine terrain, the study sites for this research lie within a large forested valley, bisected by the North Fork of the Flathead River. The national park lands upstream from our study sites remain in a near-pristine condition.

\subsection{Sampling design}

Field collections of biota were made during July and August of 1992 and 1993, 4-5 years after the Red Bench Fire. Previous studies indicate that the effects of major catchment disturbances such as wildfire continue to be manifested on stream ecosystems for 5 years or more, and thus within our sampling time-frame (Minshall et al., 1997; Hauer and Spencer, 1998). We did not attempt to quantify biomass, productivity, or diet of the aquatic biota; rather, we collected a broad array of biota across the various trophic levels for subsequent stable isotope analysis.

Fish were collected by electroshocking and preserved in $85 \%$ ethanol. Since lipids tend to be more depleted in $\mathrm{d}^{13} \mathrm{C}$ relative to the food source (DeNiro and Epstein, 1978; Tieszen et al., 1983), they were removed from the white muscle tissue of fish using a chloroform/methanol extraction (Bligh and Dyer, 1959). The remaining muscle tissue was dried at $65{ }^{\circ} \mathrm{C}$ and then freeze-dried prior to isotopic analysis.

Aquatic invertebrates were collected using kick nets as well as by direct removal of the organisms from the cobble substrate using forceps. Organisms were immediately preserved in $85 \%$ ethanol and identified using various taxonomic keys (Jenson, 1966; Morihara and McCafferty, 1979; Merritt and Cummins, 1984; Ward, 1985). Individual organisms of the same taxon were pooled to obtain sufficient quantities for 
isotopic analysis. For some of the smaller invertebrate taxa, as many as 100 individuals of each taxon were combined into a single composite sample. Taxa selected for isotopic analysis were based upon relative abundance in our field collections. For some of the less common invertebrates, particularly the smaller taxa, we did not always have enough material to measure both isotopes.

Fresh leaves were collected from the dominant terrestrial plants in the riparian zone including red-osier dogwood (Cornus stolonifera), willow (Salix sp.), mountain alder (Alnus incana), black cottonwood (Populus trichocarpa), and Douglas-fir (Pseudotsuga menziesii). To simulate the breakdown of terrestrial plant material in streams, leaves were placed in mesh bags and submerged in the streams. After 1 month, the leaf material was retrieved and prepared for isotopic analyses.

All of the terrestrial plant samples came from reference sites. We did not analyze terrestrial plant material from fire-impacted sites. Many of the trees in the riparian zone were killed by the fire. We assume that isotope ratios in the remaining terrestrial vegetation were not affected by the fire and have found nothing in the literature to suggest otherwise.

Epilithic algae were scraped directly off the upper surface of cobble substrate in the streams. In order to get sufficient quantities of organic matter for isotopic analysis, material from five or more cobbles from the same riffle area were combined into composite samples. Portions of all samples were preserved in Lugol's solution for subsequent microscopic identification using keys of Prescott (1973).

Microscopic examination of epilithon samples revealed a wide mix of algae including a variety of pennate diatoms, filamentous algae including Ulothrix sp., Nostoc sp., Draparnaldia sp., and Chlorotylium sp., as well as organic detritus, bacteria, and fungi. In addition to this mixed epilithic material, we were able to collect separate samples of filamentous algae (Ulothrix, Oscillatoria, and Nostoc) distinctly visible as stringy green clumps attached to cobble substrate. Microscopic analysis revealed these samples to be relatively free from contaminating detritus and other organisms.

Clumps of aquatic bryophytes (Fontinalis sp.) also were collected from cobble substrate in the stream riffles. Fine particulate organic matter (FPOM), was collected by filtering stream water through $1 \mathrm{~mm}$ glass fiber filters. Filtration was conducted in the field; each sample consisted of particulate matter obtained from filtering 201 of stream water. Upon return to the laboratory, the seston was scraped off the filters and dried at $95{ }^{\circ} \mathrm{C}$.

We encountered difficulties collecting sufficient quantities of some autochthonous food sources at certain sites due mainly to the low nutrient concentrations and scouring in our study streams. This was particularly true of the reference sites; for example, we had insufficient quantities of epilithon for isotopic analysis. Bunn et al. (1989) also reported similar difficulty in collecting sufficient quantities of epilithic algae for isotopic analysis in nutrient-poor streams in Quebec.

Despite sampling difficulties, we collected enough material to allow comparison of isotopic ratios for some of the autochthonous sources from both fireimpacted and reference sites. Two-way ANOVA indicated fire did not have a significant effect on $\mathrm{d}^{15} \mathrm{~N}$ or $\mathrm{d}^{13} \mathrm{C}$ values in our autochthonous samples. Given our small data base together with the absence of a significant fire effect, we combined data from reference and fire-impacted sites for autochthonous food sources in subsequent data analyses.

Prior to isotopic analysis all samples, except fish muscle, were treated with $1 \mathrm{~N} \mathrm{HCl}$ for $24 \mathrm{~h}$ to remove any potential carbonates (Rounick et al., 1982), rinsed with distilled water, dried at $65^{\circ} \mathrm{C}$ or freeze-dried, and then ground with a mortar and pestle prior to isotopic analysis. Samples of 3-35 mg, depending on the sample type, were weighed into foil containers and combusted in a Carlo Erba CHN Analyzer. The remaining $\mathrm{CO}_{2}$ and nitrogen gases were then analyzed for stable isotopes with a SIRA-10 isotope ratio mass spectrometer. Carbon samples were standardized to Peedee Belemnite and the nitrogen samples to atmospheric nitrogen. Precision was better than $0.2 \%$ for $\mathrm{C}$ and $0.5 \%$ for $\mathrm{N}$ as indicated by replicate measurements. Isotope values were calculated as:

$\mathrm{d}^{13} \mathrm{C}$ or $\mathrm{d}^{15} \mathrm{~N}=\frac{X_{\text {sample }}-X_{\text {standard }}}{X_{\text {sample }}} \times 100$

where $X={ }^{13} \mathrm{C} /{ }^{12} \mathrm{C}$ or ${ }^{15} \mathrm{~N} /{ }^{14} \mathrm{~N}$. Methods used for water sampling and water chemistry analysis are described in detail in Spencer and Hauer (1991) and Hauer and Spencer (1998). 


\section{Results and discussion}

\subsection{Overview of nutrient dynamics}

We present here a summary of post-fire water chemistry dynamics, which are described in more detail elsewhere (Spencer and Hauer, 1991; Hauer and Spencer, 1998). During the initial firestorm, phosphate, nitrate, and ammonium concentrations in the study streams increased 5- to 60-fold over background levels (Figs. 2-4). Experimental evidence indicated that the early nitrogen pulses came mainly from diffusion of smoke gases into the stream waters while the phosphorus spikes originated largely from rapid leaching of ash deposited in the streams during the firestorm. Nutrients returned to background concentrations within several weeks after the fire. During subsequent years, nutrient concentrations periodically increased in fire-impacted sites compared to reference sites, especially during spring run-off. Other studies also report large increases in stream nutrient concentrations following fire (Tiedemann et al., 1978; Gluns and Toews, 1989; Bayley et al., 1992; Chorover et al.,
1994; Saa et al., 1994; Brass et al., 1996). Interestingly, increased stream nutrient loadings in these other fires have typically been attributed to overland flow and subsurface transport following the fire. While such modes of transport likely were important on the Red Bench Fire during the post-fire years, overland and subsurface transport were not likely immediately after the fire when nutrient concentrations reached their highest levels. The Red Bench Fire occurred during a period of prolonged drought, and there was little opportunity for accelerated transport of nutrients to the streams by any type of water-borne transport for the first 6 weeks of the fire. Aerial transport of inorganic nutrients to streams, via ash and smoke, was the likely mode of short-term nutrient delivery, during and immediately after the Red Bench Fire (Spencer and Hauer, 1991).

Other studies report volatilization of various forms of gaseous nitrogen to the atmosphere from combustion of vegetation during intense wildfire (see reviews by Grier, 1975; Raison, 1979). Additional researchers have reported windblown and convective transfer of ash during fires and that ash may contain substantial
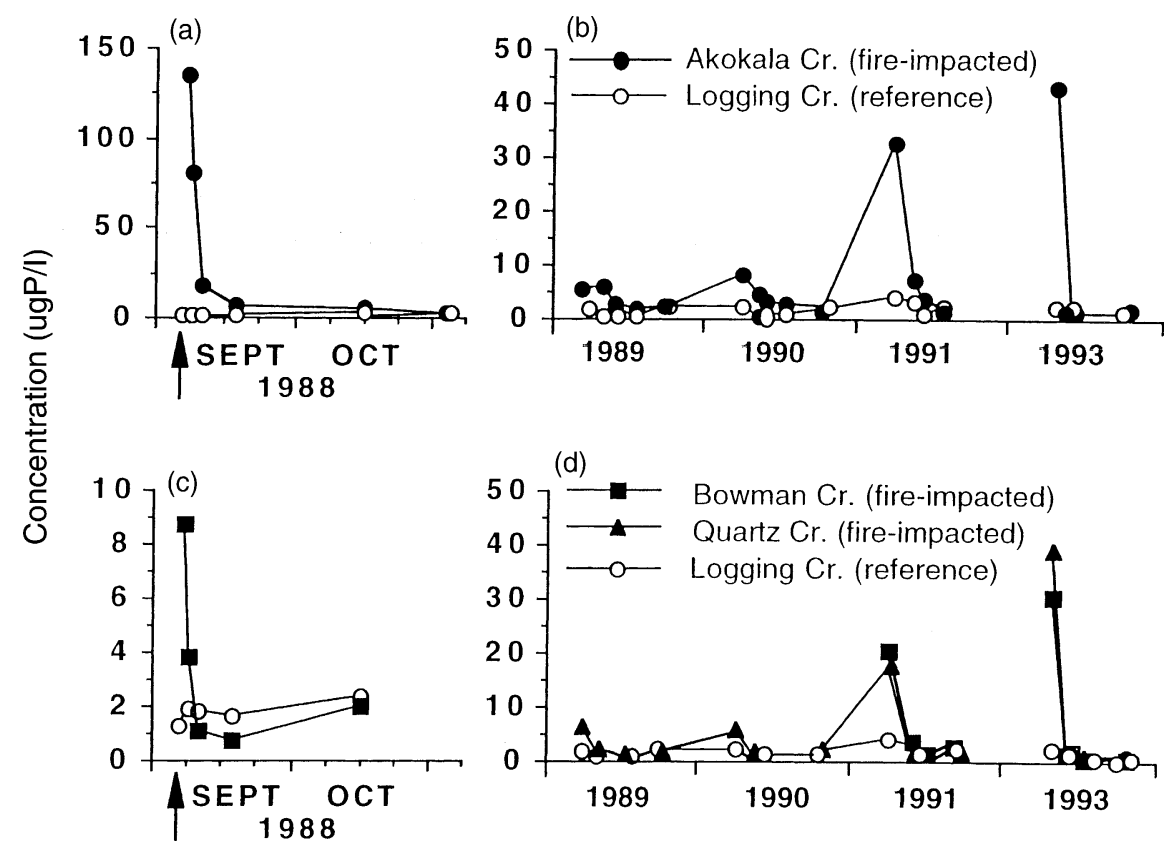

Fig. 2. Time course measurements of soluble reactive phosphorus (SRP) in various fire-impacted and reference sites. Arrow indicates the beginning of the Red Bench Fire on 6 September 1988 (redrawn from Hauer and Spencer, 1998). 

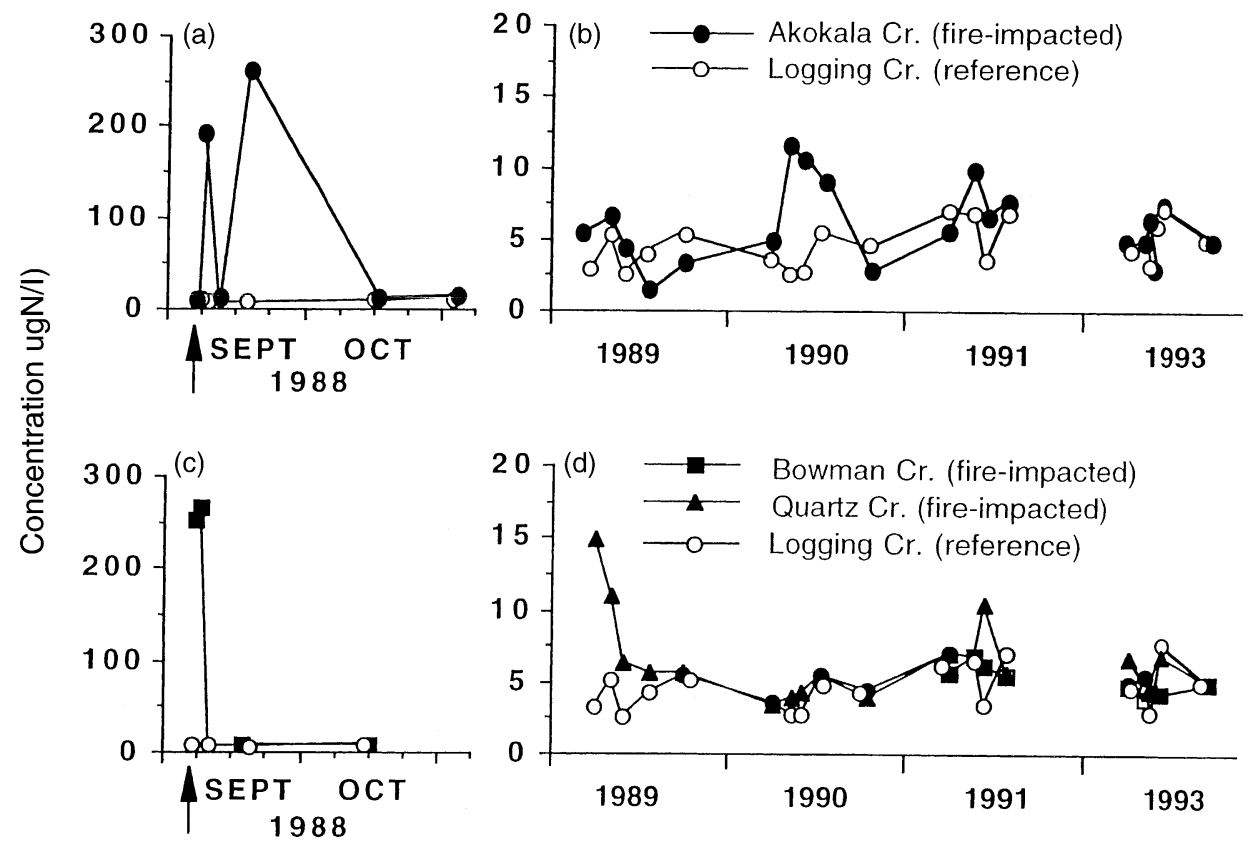

Fig. 3. Time course measurements of ammonium in various fire-impacted and reference sites. Arrow indicates the beginning of the Red Bench Fire on 6 September 1988 (redrawn from Hauer and Spencer, 1998).
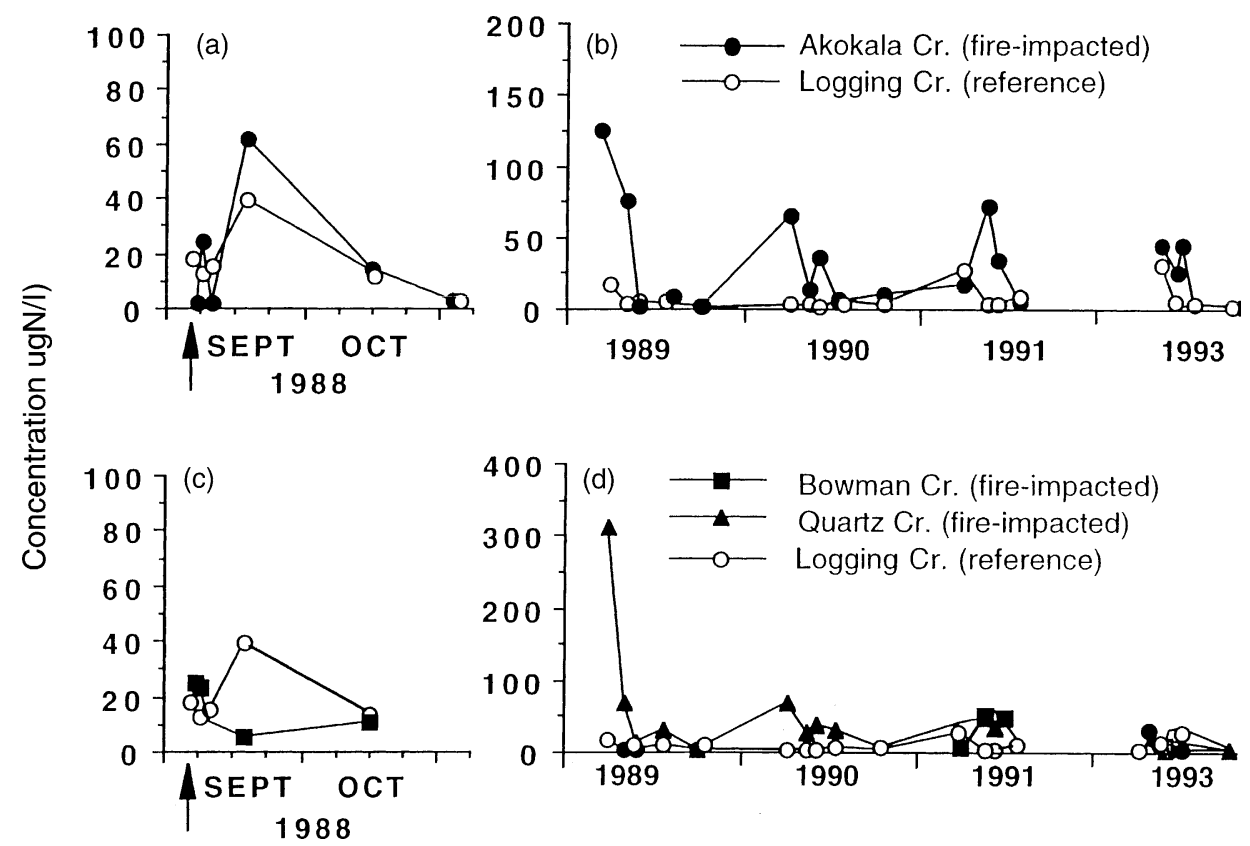

Fig. 4. Time course measurements of nitrate in various fire-impacted and reference sites. Arrow indicates the beginning of the Red Bench Fire on 6 September 1988 (redrawn from Hauer and Spencer, 1998). 
amounts of leachable phosphate (Trabaud, 1994). The nitrogen and phosphorus carried in smoke and ash tends to be present in highly available forms. During the height of the Red Bench firestorm, SRP accounted for over $80 \%$ of the total phosphorus loading in the fire-impacted sites, compared to less than $25 \%$ at reference sites (Spencer and Hauer, 1991). Similarly, ammonium and nitrate made up a considerable portion of the total nitrogen pool in fire-impacted streams, exceeding 90\% during peak fire activity (Spencer and Hauer, 1991). Goldman et al. (1990) attributed increased primary production in Lake Tahoe to atmospheric deposition of nutrients transported from several large fires in 1985. Lewis (1974) also suggested the potential importance of atmospheric transport of nutrients to surface waters, in studies of a prescribed burn in a South Carolina pine forest. However, due to logistical constraints many studies of intense wildfires do not include surface water samples collected during the actual firestorms. Consequently, the potential for substantial, short-term transport of nutrients to surface waters during large fires has probably been frequently overlooked. It would be interesting in future fire studies to include use not only of dryfall collectors for collection of ash and other particulate material, but also a water bath or other device for monitoring of nutrient loadings from smoke and related gaseous compounds.

\subsection{Biotic responses}

\subsubsection{Short-term impacts}

We observed a number of dead fish in the study streams the day after passage of the initial firestorm. Most of these fish were small $(<10 \mathrm{~cm})$ westslope cutthroat trout (Oncorhynchus clarki lewisi). The fish may have been killed by elevated temperatures during the height of the firestorm. Unfortunately, we did not have temperature loggers in the study streams during the firestorm. The fish also may have been stressed by diffusion of smoke gases or other water chemistry changes during the firestorm, including high ammonia levels or other volatile compounds.

In addition to fish-kills, we noted other biotic impacts during the first spring after the Red Bench Fire. Immediately after snowmelt, we noted numerous puddles, ponds, and rivulets in the burned catchments that were bright green from exceedingly dense algae blooms. In several decades of work in Glacier National Park we had never before witnessed comparable algae blooms. Subsequent observations on these temporary water bodies in later years showed that these algae blooms did not reappear.

\subsubsection{Long-term biotic impacts via stable isotope analysis}

Stable isotope analysis of fish and macroinvertebrates gave evidence of fire-related effects coursing through the food web (Figs. 5 and 6). Before discussing fire effects on isotope ratios, we make note of an obvious increase in $\mathrm{d}^{15} \mathrm{~N}$ as a function of increasing trophic level in both fire-impacted and reference sites (Fig. 5b). Fish had the highest $\mathrm{d}^{15} \mathrm{~N}$ values (7-8.5\%) compared to herbivorous macroinvertebrates (shredders and scrapers; $0.5-3.5 \%$ ). Such results are consistent with other studies reporting a 1.5-5.0\%o increase in $\mathrm{d}^{15} \mathrm{~N}$ with each trophic transfer (Minagawa and Wada, 1984; Fry, 1991). We found little evidence of similar trophic level effect on $\mathrm{d}^{13} \mathrm{C}$ (Fig. 6b) which is consistent with other studies (DeNiro and Epstein, 1978; Peterson and Fry, 1987; Fry, 1991).

Stable isotope analysis revealed that fish and macroinvertebrates from fire-impacted sites showed a consistent shift in $\mathrm{d}^{15} \mathrm{~N}$ and $\mathrm{d}^{13} \mathrm{C}$ values compared to organisms from reference sites (Figs. $5 b$ and $6 b$ ). Consumers from fire-impacted sites were more enriched in ${ }^{15} \mathrm{~N}$ and more depleted in ${ }^{13} \mathrm{C}$ than consumers from reference sites. Although the magnitude of these isotopic shifts was relatively small, averaging $\sim 1 \%$ or $\mathrm{d}^{13} \mathrm{C}$ and $\sim 0.5 \%$ or $\mathrm{d}^{15} \mathrm{~N}$, the differences were highly significant for both isotopes $(P<0.001$, two-way ANOVA).

A number of researchers have linked shifts in stable isotope ratios in aquatic consumers to dietary shifts involving ingestion of food items with different isotopic signatures (Rau, 1980; Peterson and Fry, 1987; Fry, 1991; Hesslein et al., 1993). For example, several studies report a similar reduction in $\mathrm{d}^{13} \mathrm{C}$ in a variety of consumer organisms following experimental logging and burning of small catchments in New Zealand and attribute the isotopic shift to increased use of autochthonous energy sources following canopy removal (Rounick et al., 1982; Rounick and Hicks, 1985; Rounick and Winterbourn, 1986). Similarly, Winterbourn et al. (1986) reported that macroinvertebrates from open-canopied stream sites in UK were more 

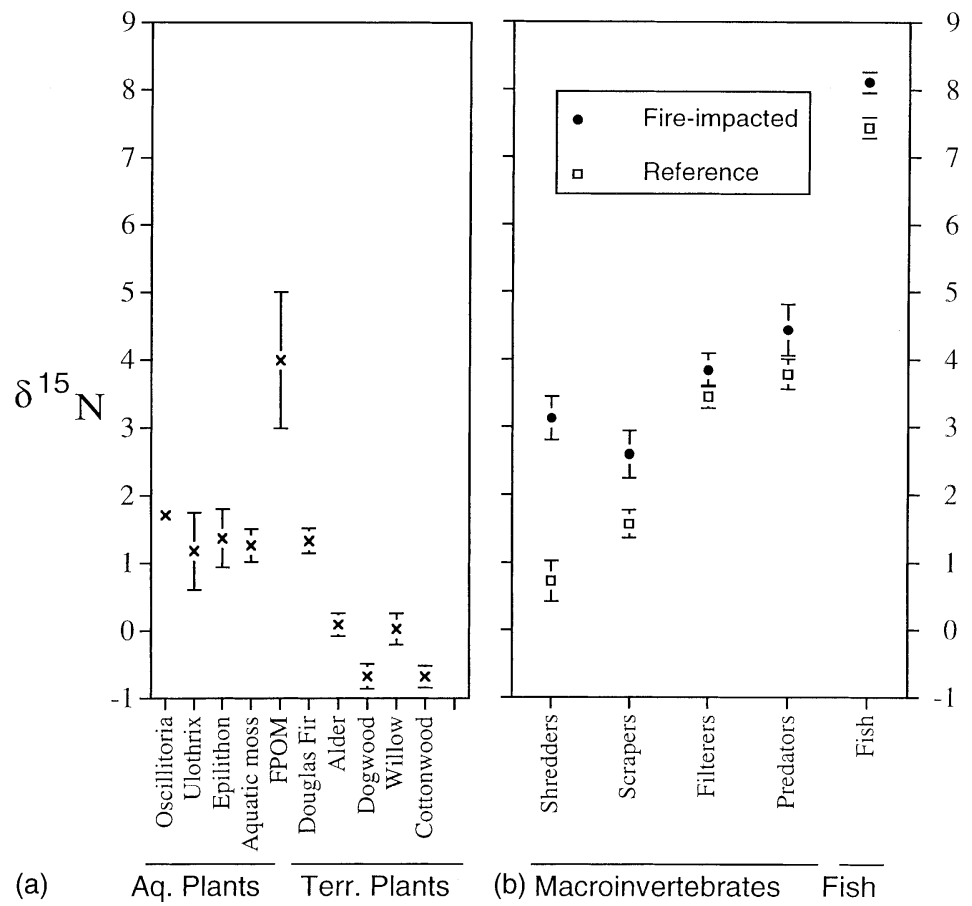

Fig. 5. The distribution of $d^{15} \mathrm{~N}$ values in (a) potential food sources and (b) macroinvertebrates and fish from forested reference sites and fireimpacted sites on Akokala and Bowman creeks in Glacier National Park. Data are mean \pm 1 S.E.
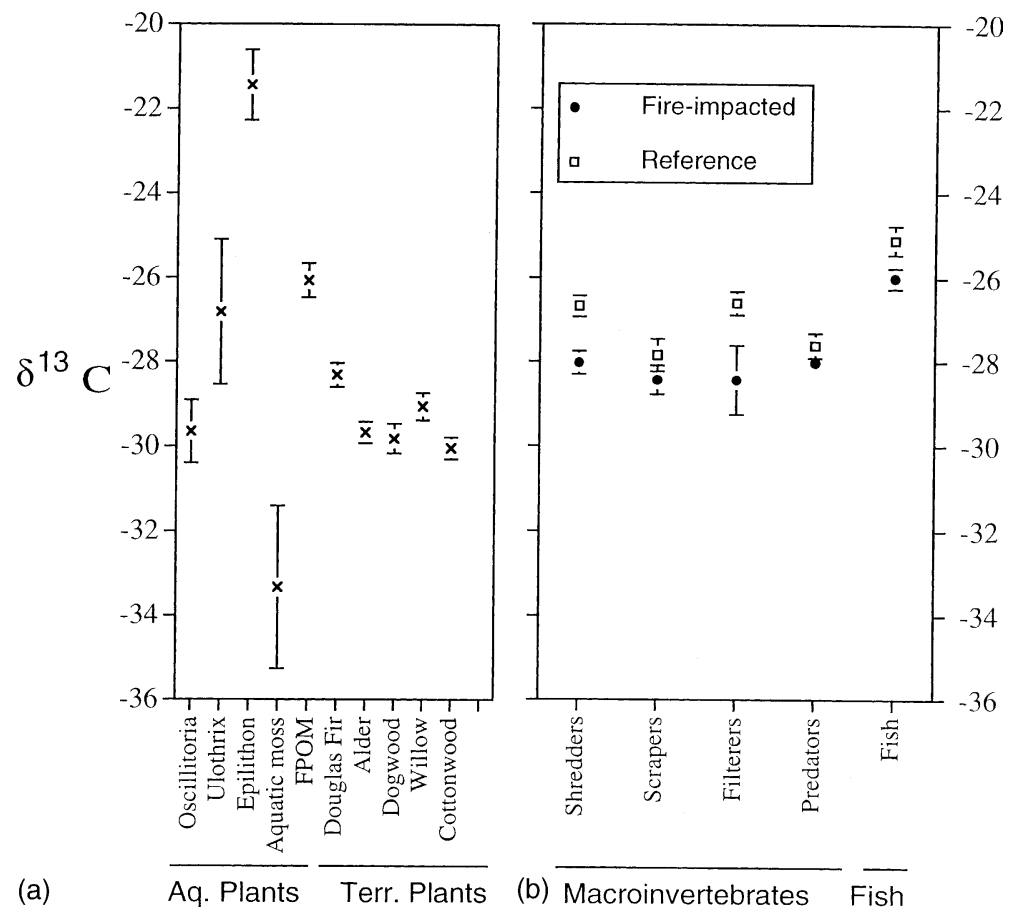

Fig. 6. The distribution of $\mathrm{d}^{13} \mathrm{C}$ values in (a) potential food sources and (b) macroinvertebrates and fish from forested reference sites and fire-impacted sites on Akokala and Bowman creeks in Glacier National Park. Data are mean \pm 1 S.E. 
depleted in ${ }^{13} \mathrm{C}$ than consumers from closed-canopied forested sites. The isotopic shift in consumers was attributed to greater use of more-depleted autochthonous food sources in the cleared and open sites.

We looked for evidence of a post-fire dietary shift in consumer organisms by comparing stable isotope ratios of consumers with isotope ratios of various potential food sources (Figs. 5a and 6a). Stable isotopes are only effective as energy flow tracers if there are distinct isotopic differences between various potential food sources. We found clear differences in $\mathrm{d}^{15} \mathrm{~N}$ values among some of the primary producers and other potential food sources (Fig. 5a). All of the autochthonous food sources were more enriched in ${ }^{15} \mathrm{~N}$ than leaves from the four deciduous tree species $(P<0.05$, Tukey-Kramer post-hoc test). Attached algae, including composite epilithon scrapings as well as distinct clumps of filamentous algae Ulothrix sp. and Oscillatoria sp. as well as the aquatic bryophyte Fontinalis sp. had mean $\mathrm{d}^{15} \mathrm{~N}$ values of $1.2-1.7 \%$. By contrast, alder, dogwood, willow, and cottonwood had mean $\mathrm{d}^{15} \mathrm{~N}$ values of $-0.7-0.0 \%$. Douglas-fir needles, with a mean $\mathrm{d}^{15} \mathrm{~N}$ value of $1.3 \%$, were indistinguishable from the autochthonous food sources.

In a review of other stable isotope studies, France (1995b) also reported that autochthonous food sources had higher $\mathrm{d}^{15} \mathrm{~N}$ values than terrestrial food sources and concluded that these differences are "substantial enough to be reflected by progressive ${ }^{15} \mathrm{~N}$ enrichment in consumers along a gradient from terrestrial to freshwater (environments)". Extending this analysis to our study, the consistent increase in $\mathrm{d}^{15} \mathrm{~N}$ values noted in consumers from fire-impacted sites (Fig. 5b) could be explained by increased use of more-enriched autochthonous food sources following the fire (Fig. 5a).

Although we did not quantify primary production in the aquatic or terrestrial environment, other evidence points to a likely increase in autochthonous production in the study streams following the fire. Prior to the fire, the third-order study streams were heavily forested throughout much of their catchments. Removal of riparian vegetation following the fire greatly increased light penetration to the stream surface, likely stimulating autochthonous production, as has been reported in other studies following canopy removal by various means (Hansmann and Phinney, 1973; Stockner and Shortreed, 1976). In addition, increased nutrient loadings described earlier also likely contributed to increased autochthonous production following the fire, as has been documented in a number of experimental nutrient-addition studies (Bothwell, 1985; Lowe et al., 1986; Peterson et al., 1993).

Following the 1988 fire season in nearby Yellowstone National Park, Minshall et al. (1989) predicted a shift from allochthonous to autochthonous energy sources in stream food webs. Results from our $\mathrm{d}^{15} \mathrm{~N}$ analysis appear to be consistent with this prediction. Interestingly, research by Minshall and colleagues now shows that periphyton biomass actually decreased in a number of streams in Yellowstone Park following the 1988 fire-season (Robinson et al., 1994; Minshall et al., 1995, 1997). These studies attributed decreased periphyton growth to physical disturbance of the stream channel, including post-fire bed scouring, channel alteration, and sedimentation. By contrast, we found no evidence of major physical disturbance of stream channels following the Red Bench Fire in Glacier National Park, other than a fine coating of ash covering most of the benthic substrate immediately after the fire (Spencer and Hauer, 1991). While the Yellowstone fires burned through areas of steep terrain, the burned areas of the Akokala and Bowman creek catchments are characterized by gentle terrain, lying largely within the floodplain of North Fork Flathead River. Furthermore, we observed little surface erosion following the Red Bench Fire due in part to a reduced winter snow-pack and a lack of heavy rains which combined to produce mild run-off the year after the fire. Consequently, burned areas revegetated quickly in Glacier National Park and stream channels appeared largely undisturbed, setting the stage for potential increases in autochthonous production following the fire.

There are several alternative mechanisms that could explain the shift in $\mathrm{d}^{15} \mathrm{~N}$ values in fire-impacted streams. Since Douglas-fir was indistinguishable from autochthonous food sources based upon $\mathrm{d}^{15} \mathrm{~N}$ analysis (Fig. 5a), the post-fire ${ }^{15} \mathrm{~N}$ enrichment noted in consumers would also be consistent with a shift from a diet dominated by deciduous leaf material to one dominated by Douglas-fir. This scenario seems improbable as aquatic herbivores tend to prefer deciduous leaf material over coniferous leaf material (Friberg and Jacobsen, 1995; Maloney and Lamberti, 1995). Furthermore, we saw no visual evidence that input of leaf material from Douglas-fir increased 
relative to deciduous species following the fire. Another possible explanation for post-fire increase in $\mathrm{d}^{15} \mathrm{~N}$ in consumers was increased assimilation of fine particulate organic matter, which had higher $\mathrm{d}^{15} \mathrm{~N}$ values than any of the other potential food sources (Fig. 5a). However, we do not think increased reliance on FPOM is a primary contributor to the observed isotopic shift in consumers since shredders and scrapers are not well equipped to filter FPOM from the stream waters and these two functional feeding groups comprised over two-thirds of the macroinvertebrate taxa collected in our study.

We found much more overlap in $\mathrm{d}^{13} \mathrm{C}$ values among various potential food sources than with $\mathrm{d}^{15} \mathrm{~N}$ (Fig. 6a). Mean values ranged from $-21.5 \%$ for epilithon to $-33.3 \%$ for aquatic moss (Fontinalis sp.). A number of allochthonous and autochthonous food sources had overlapping $\mathrm{d}^{13} \mathrm{C}$ values between -26 and $-30 \%$. France (1995a) and Mize (1993) also reported considerable overlap in $\mathrm{d}^{13} \mathrm{C}$ values among allochthonous and autochthonous food sources, making it less useful for assessing dietary shifts in consumer organisms. An additional constraint with our $\mathrm{d}^{13} \mathrm{C}$ data was the relatively high variability between replicates, especially within the autochthonous food sources (Fig. 6a).

Given these constraints, we can only speculate as to the potential cause of the lower $\mathrm{d}^{13} \mathrm{C}$ values noted in consumers from fire-impacted sites (Fig. 6b). Increased feeding on highly depleted aquatic mosses or somewhat depleted Oscillatoria following the fire could have led to lower $\mathrm{d}^{13} \mathrm{C}$ values in consumers. Although aquatic mosses are not normally considered to be widely used as food sources by stream invertebrates (Hynes, 1970), several studies have documented feeding by macroinvertebrates on aquatic mosses (Williams and Williams, 1979; Willoughby and Mappin, 1988). Deciduous tree leaves were also relatively depleted in $\mathrm{d}^{13} \mathrm{C}$, and increased use of this food source could have reduced $\mathrm{d}^{13} \mathrm{C}$ levels in consumers following the fire. However, this explanation would contradict the findings of other studies which report reduced use of allochthonous food sources following canopy removal (Hansmann and Phinney, 1973; Rounick and Winterbourn, 1986).

Taken together, our data show a clear shift in consumer organisms between fire-impacted and reference sites for $\mathrm{d}^{15} \mathrm{~N}$ and $\mathrm{d}^{13} \mathrm{C}$ (Figs. 5 and 6). Although our stable isotope data do not allow definitive con- clusions to be drawn as to the cause of this shift, our data and the large body of work within the river continuum concept lead us to suggest that the most likely explanation for the isotopic shift in consumers involves increased use of autochthonous food sources following the fire. After the 1988 fires in Yellowstone, Mihuc and Minshall (1995) found that benthic macroinvertebrates were dominated by trophic generalists that appeared well-adapted to shifting between allochthonous and autochthonous food sources. It would be interesting to repeat the stable isotope analysis following recovery of the forest canopy, to see if stable isotope ratios in consumers revert back to reference site values.

\subsection{Management implications}

Forest managers are now contemplating widely expanded use of fire in an attempt to reduce fuel build-up in forests throughout the western US. As with most natural resource management issues, there are numerous trade-offs to be considered. Since fires represent a natural disturbance, enhanced fire activity in the future could represent a return to more natural conditions. However, increased fire activity could exacerbate another environmental concern: lake eutrophication. As shown in our study and others, fires can mobilize substantial quantities of highly available nutrients to lakes and streams. Over a decade ago, Goldman et al. (1990) reported that primary productivity in Lake Tahoe was stimulated by increased nutrient loadings associated with forest fires. During the extensive fire season of 1988, smoke and haze were visible across much of western Montana from June to mid-October and Flathead Lake experienced the highest levels of primary productivity measured over the last four decades (Stanford, 2002).

During the summer months, the epilimnetic waters of many lakes often become nutrient depleted due to reduced river inputs together with the isolation of nutrients in the colder hypolimnetic zone (Wetzel, 2001). However, smoke and ash-fall from summer fires could deliver a steady stream of highly available nitrogen and phosphorus to nutrient-depleted surface waters, thereby stimulating phytoplankton growth.

Since smoke and ash-fall represent potential pathways for substantial nutrient transport, increased nutrient loadings to surface waters from fires may 
extend well beyond the catchment of a particular fire. During spring and fall, it is common to see a visible haze of smoke permeating the atmosphere in the northwestern US, particularly in river and lake valleys. It is during these seasons that slash piles, recently logged areas, and agricultural lands (particularly wheat-growing areas of eastern Washington) are commonly burned. Smoke plumes from individual slash and burn operations have been tracked for $60 \mathrm{~km}$ at elevations up to $4000 \mathrm{~m}$ (Debyle, 1981).

Beginning in the 1960s and 1970s, much effort has been directed at reducing nutrient inputs to surface waters in response to eutrophication concerns. Among these many efforts include construction of tertiary wastewater treatment plants, expanded use of no-till agriculture, and streamside buffer zones in logging sites and agricultural fields. Through mandates of the Clean Water Act, the US Environmental Protection Agency is currently spearheading efforts across the country to establish total maximum daily loads of nutrients to lakes at risk of eutrophication. Thus, natural resource managers contemplating expanded use of fire as a forest restoration tool face the dilemma that such efforts could run counter to a decades-long effort to reduce nutrient loadings to lakes and other surface waters threatened by eutrophication.

It might be argued that increased fire activity in the future may represent a return to more natural conditions. Prior to European settlement, wildfires were part of the natural ecosystem of the northern Rocky Mountains and may well have increased nutrient loadings to surface waters. However, we expect that the frequencies would have been quite different. Evidence from paleolimnology and dendrochronology indicates a typical pre-European, fire frequency in the northern Rocky Mountains ranging from decades to several hundred years, depending upon the area (Barrett et al., 1991; Millspaugh et al., 2000). However, the frequency of more recent fire activity could well represent an almost chronic annual loading of smoke and ash in some cases resulting from seasonal burning of logging slash and agricultural fields, together with the possibility of increased prescribed forest burning as well as increased wildfire activity following years of fire suppression.

Although there are an increasing number of studies evaluating impacts of fires on aquatic ecosystems, there remains a scarcity of data collected in the midst of large forest fires. We encourage more such studies, especially those attempting to quantify aerial transport and deposition of nutrients during fire activity and subsequent impacts on aquatic ecosystems. To this end, it would be interesting to consider fire safety training for interested research scientists in order that they might be suitably equipped to conduct their fieldwork in concert with other fire personnel.

\section{Acknowledgements}

For help with field work, we thank Chuck Levitan, Mark Spencer, Brent Loken, Robbin Wagner, Barb Kelly, Gretchen Umlaf, Sean Meegan, Jack Webster, and Vince Resh. The paper benefited from helpful reviews by Wayne Minshall and David Pilliod.

\section{References}

Baker, M.B., 1990. Hydrologic and water quality effects of fire. In: Krammes, J.S. (Ed.), Effects of Fire Management of Southwestern Natural Resources. USDA For. Serv. Gen. Tech. Rep. RM-191, pp. 31-42.

Barrett, S.W., Arno, S.F., Key, C.H., 1991. Fire regimes of western larch-lodgepole pine forests in Glacier National Park, Montana. Can. J. Forest Res. 21, 1711-1720.

Bligh, E.G., Dyer, W.J., 1959. A rapid method of total lipid extraction and purification. Can. J. Biochem. Biophys. 37, 911-917.

Bothwell, M.L., 1985. Phosphorus limitation of lotic periphyton growth rates: an intersite comparison using continuous-flow troughs (Thompson River system, British Columbia). Limnol. Oceanogr. 30, 527-542.

Brass, J.A., Ambrosia, V.G., Riggan, P.J., Sebesta, P.D., 1996. Consequences of fire on aquatic nitrate and phosphate dynamics in Yellowstone National Park. Int. Assoc. Wildland Fire 6, 53-57.

Bunn, S.E., Barton, D.R., Hynes, H.B.N., Power, G., Pope, M.A., 1989. Stable isotope analysis of carbon flow in a tundra river system. Can. J. Fish Aquat. Sci. 46, 1769-1775.

Cummins, K.W., Sedell, J.R., Swanson, F.J., Minshall, G.W., Fisher, S.G., Cushing, C.E., Peterson, R.C., Vannote, R.L., 1982. Organic matter budgets for stream ecosystems: problems in their evaluation. In: Minshall, G.W., Barnes, J.R. (Eds.), Stream Ecology: Application and Testing of General Ecological Theory. Plenum Press, New York, pp. 299-353.

DeNiro, M.J., Epstein, S., 1978. Influence of diet on the distribution of carbon isotopes in animals. Geochim. Cosmochim. Acta 42, 495-506.

Feminella, J.W., Power, M.E., Resh, V.H., 1989. Periphyton responses to invertebrate grazing and riparian canopy in 
three northern California coastal streams. Freshwater Biol. 22 , 445-457.

Fisher, S.G., Likens, G.E., 1973. Energy flow in Bear Brook, New Hampshire: an integrative approach to stream ecosystem metabolism. Ecol. Monogr. 43, 421-439.

France, R., 1995a. Critical examination of stable isotope analysis as a means for tracing carbon pathways in stream ecosystems. Can. J. Fish. Aquat. Sci. 52, 651-656.

France, R.L., 1995b. Source variability in $\mathrm{d}^{15} \mathrm{~N}$ of autotrophs as a potential aid in measuring allochthony in freshwaters. Ecography $18,318-320$.

Friberg, N., Jacobsen, D., 1995. Feeding plasticity of two detritavores. Freshwater Biol. 32, 133-142.

Fry, B., 1991. Stable isotope diagrams of freshwater food webs. Ecology 72, 2293-2297.

Gluns, D.R., Toews, D.A.A., 1989. Effect of a major wildfire on water quality of Southeastern British Columbia. In: Potts, D.F., Woessner, W.W. (Eds.), Proceedings of the Symposium on Hardwaters Hydrology. American Water Resources Association, Bethesda, MD.

Hansmann, E.W., Phinney, H.K., 1973. Effects of logging on periphyton in coastal streams of Oregon. Ecology 54, 194-199.

Hauer, F.R., Spencer, C.N., 1998. Phosphorus and nitrogen dynamics in streams associated with wildfire: a study of immediate and long-term effects. Int. J. Wildland Fire 8, 183-198.

Hynes, H.B.N., 1970. The Ecology of Running Waters. University of Toronto Press, Toronto, Ont., p. 555.

Jenson, S.L., 1966. The mayflies of Idaho. M.Sc. thesis, University of Utah, p. 367.

Lowe, R.L., Golladay, S.W., Webster, J.R., 1986. Periphyton response to nutrient manipulation in streams draining cleared and forested watersheds. J. North Am. Benthol. Soc. 5, 221-229.

Maloney, D.C., Lamberti, G.A., 1995. Rapid decomposition of summer-input leaves in a northern Michigan stream. Am. Midl. Nat. 133, 184-195.

Merritt, R.W., Cummins, K.W., 1984. Aquatic Insect of North America, second ed. Kendall/Hall Publisher, Dubuque, Iowa, p. 722 .

Mihuc, T.B., Minshall, G.W., 1995. Trophic generalists vs. trophic specialists: implications for food web dynamics in post-fire streams. Ecology 76, 2361-2372.

Millspaugh, S.H., Whitlock, C., Bartlein, P.J., 2000. Variations in fire frequency and climate over the past 17,000 years in central Yellowstone National Park. Geology 28, 211-214.

Minagawa, M., Wada, E., 1984. Stepwise enrichment of ${ }^{15} \mathrm{~N}$ along food chains: further evidence and the relation between $\mathrm{d}^{15} \mathrm{~N}$ and animal age. Geochim. Cosmochim. Acta 48, 11351140 .

Minshall, G.W., 1967. Role of allochthonous detritus in the trophic structure of a woodland spring brook community. Ecology 48, 139-149.

Minshall, G.W., Brock, J.T., Varley, J.D., 1989. Wildfires and Yellowstone's stream ecosystems. Bioscience 39, 707-715.

Minshall, G.W., Robinson, C.T., Royer, T.V., Rushforth, S.R., 1995. Benthic community structure in two adjacent streams in
Yellowstone National Park 5 years after the 1988 wildfires. Great Basin Naturalist 55, 193-200.

Minshall, G.W., Robinson, C.T., Lawrence, D.E., 1997. Postfire responses of lotic ecosystems in Yellowstone National Park, USA. Can. J. Fish. Aquat. Sci. 54, 2509-2525.

Mize, A.L., 1993. Differential utilization of allochthonous and autochthonous carbon by aquatic insects of two shrub-steppe desert spring-streams: a stable carbon isotope analysis and critique of the method. Ph.D. thesis, Old Dominion University, US Department of Energy, Batelle Memorial Institute, Richland, WA.

Morihara, D.K., McCafferty, W.P., 1979. The Baetis larvae of North America (Ephemeroptera:Baetidae). Trans. Am. Ent. Soc. 105, 139-221.

Peterson, B.J., Fry, B., 1987. Stable isotopes in ecosystem studies. Annu. Rev. Ecol. Syst. 18, 293-320.

Peterson, B.J., Deegan, L., Helfrish, J., Hobbie, J.E., Hullar, M., Moller, B., Ford, T.E., Hershey, A., Hiltner, A., Kipphut, G., Lock, M.A., Fiebig, D.M., McKinley, V., Miller, M.C., Vestalo, J.R., Ventullo, R., Volk, G., 1993. Biological responses of a tundra river to fertilization. Ecology 74, 653672.

Rau, G.H., 1980. Carbon-13/carbon-13 variation in subalpine lake aquatic insects: food source implications. J. Fish. Res. Board Can. 37, 742-746.

Rounick, J.S., Hicks, B.J., 1985. The stable carbon isotope ratios of fish and their invertebrate prey in four New Zealand rivers. Freshwater Biol. 15, 207-214.

Rounick, J.S., Winterbourn, M.J., 1986. Stable carbon isotopes and carbon flow in ecosystems. Bioscience 36, 171-177.

Rounick, J.S., Winterbourn, M.J., Lyon, G.M., 1982. Differential utilization of allochthonous and autochthonous inputs by aquatic invertebrates in some New Zealand streams: a stable carbon isotope study. Oikos 39, 191-198.

Spencer, C.N., Hauer, F.R., 1991. Phosphorus and nitrogen dynamics in streams during a wildfire. J. North Am. Benthol. Soc. 10, 24-30.

Stanford, J.A., 2002. State of the lake 2002 monitoring water quality in Flathead Lake, Montana. Annual Report, Flathead Basin Commission and Flathead Lake Biological Station, Polson, Montana.

Stockner, J.G., Shortreed, K.R.S., 1976. Autotrophic production in Carnation Creek, a coastal rainforest stream on Vancouver Island, British Columbia. J. Fish. Res. Board Can. 33, 15531563.

Tiedemann, A.R., Helvey, J.D., Anderson, T.D., 1978. Stream chemistry and watershed nutrient economy following wildfire and fertilization in Eastern Washington. J. Environ. Qual. 7, 580-588.

Tiedemann, A.R., Conrad, C.E., Dieterich, J.H., Hornbeck, J.W., Megahan, W.F., Viereck, L.A., Wade, D.D., 1979. Effects of fire on water. USDA For. Serv. Gen. Tech. Rep. WO-10.

Tieszen, L.L., Boutton, T.W., Tesdahl, K.G., Slade, N.A., 1983. Fractionation and turnover of stable carbon isotopes in animal tissues: implications for $\mathrm{d}^{13} \mathrm{C}$ analysis of diet. Oecologia 57 , 32-37. 
Vannote, R.L., Minshall, G.W., Cummins, K.W., Sedell, J.R., Cushing, C.E., 1980. The river continuum concept. Can. J. Fish. Aquat. Sci. 37, 130-137.

Ward, J.V., 1985. An Illustrated Guide to the Mountain Stream Insects of Colorado. Kinko's Professor Publishing, p. 199.

Williams, N.E., Williams, D.D., 1979. Distribution and feeding records of the caddisflies (Trichoptera) of the Matamek River region, Quebec. Can. J. Zool. 57, 2402-2412.
Willoughby, L.G., Mappin, R.G., 1988. The distribution of Ephemerella ignita (Ephemeroptera) in streams: the role of $\mathrm{pH}$ and food resources. Freshwater Biol. 19, 145-155.

Winterbourn, M.J., Rounick, S.J., Hildrew, A.G., 1986. Patterns of carbon resource utilization by benthic invertebrates in two British river systems: a stable carbon isotope study. Arch. Hydrobiol. 107, 349-361. 